\title{
Impacts of rumen fluid modified by feeding Yucca schidigera to lactating dairy cows on in vitro gas production of 11 common dairy feedstuffs, as well as animal performance
}

\author{
M.D. Singer ${ }^{\text {a,* }}$, P.H. Robinson ${ }^{\text {a }}$, A.Z.M. Salem ${ }^{\text {b }}$, E.J. DePeters ${ }^{\text {a }}$ \\ ${ }^{a}$ Department of Animal Science, University of California, Davis, CA 95616, USA \\ ${ }^{\mathrm{b}}$ Department of Animal Production, University of Alexandria, Alexandria, Egypt
}

Received 22 August 2007; received in revised form 10 December 2007; accepted 21 December 2007

\begin{abstract}
The objective was to determine effects of feeding increasing levels of a Yucca schidigera extract (YSE) to dairy cows on $24 \mathrm{~h}$ in vitro gas production and $27 \mathrm{~h}$ in vitro neutral detergent fibre (aNDFom) digestion of 11 common dairy feedstuffs, as well as in vivo rumen fermentation and performance of the cows to which the YSE was fed. The principle was to use YSE to potentially modify the rumen microbial population in vivo and measure subsequent impacts of the adapted rumen fluid on feedstuff fermentation in vitro. Four rumen cannulated late lactation Holstein cows ( $810 \pm 54.7 \mathrm{~kg}$ body weight) were used in a $4 \times 4$ Latin Square design experiment with $14 \mathrm{~d}$ periods. Cows were housed in pens with individual feeding gates and had ad libitum access to water while fed a total mixed ration (TMR) of alfalfa hay, corn grain, barley grain, dried distillers grains, whole cottonseed, beet pulp, soybean meal, almond hulls, rumen inert fat and a mineral/salt mixture. Based upon sarsaponin assay of four commercial YSE products, Monterey Sarsaponin $15^{\circledR}$ was selected and added to the TMR to provide $0,5,10$ or $15 \mathrm{~g}$ of sarsaponin/cow/d. Rumen fluid from each cow in each period was utilized for in vitro gas determinations to measure gas production and aNDFom digestion from the
\end{abstract}

Abbreviations: ADFom, acid detergent fibre; BW, body weight; aNDFom, neutral detergent fibre; dNDF30, NDFom digestible at $30 \mathrm{~h}$ of in vitro fermentation; $\mathrm{CP}$, crude protein; NE, net energy; TMR, total mixed ration; VFA, volatile fatty acid; YSE, Yucca schidigera extract.

* Corresponding author at: College of Veterinary Medicine, Western University of Health Science, Pomona, CA 91766, USA. Tel.: +19095102066.

E-mail address: MSinger@WesternU.Edu (M.D. Singer). 
test feeds. There was a strong linear effect $(\mathrm{P}=0.002)$, at an increasing rate (quadratic $\mathrm{P}=0.08)$, to increased extent of gas production with increased feeding of YSE. There was a quadratic effect to maximum rate of gas production $(\mathrm{P}=0.01)$ at the $5 \mathrm{~g}$ sarsaponin level. At $4 \mathrm{~h}$ of fermentation, gas production increased linearly $(\mathrm{P}<0.05)$, at an increasing rate $(\mathrm{P}<0.002)$, for almond hulls, barley grain and soybean meal with increasing levels of YSE. Gas production from barley grain had a quadratic effect $(\mathrm{P}<0.01)$, suggesting a maximum at about the $5 \mathrm{~g}$ sarsaponin feeding level. Gas production at $24 \mathrm{~h}$ of fermentation increased linearly $(\mathrm{P}=0.03)$, at a decreasing rate $(\mathrm{P}<0.03)$, but only soybean meal had a quadratic tendency $(\mathrm{P}=0.08)$ to minimum gas production at about the $5 \mathrm{~g}$ level of sarsaponin. In vitro fermentation of aNDFom at $27 \mathrm{~h}$ was not impacted by treatment. In vivo rumen $\mathrm{pH}$, concentrations of total volatile fatty acids and rumen protozoal counts were not impacted by YSE feeding level, as were milk production, milk components and net energy (NE) balance. However, correlations between $\mathrm{NE}$ output and the proportional increases in $4 \mathrm{~h}$ gas production with increasing levels of YSE in the diet suggest that this measure may be predictive of animal responses to this YSE. Finally, multivariate analysis, used to create equations to predict impacts of the nutrients in the 11 feedstuffs on their proportional increase in $4 \mathrm{~h}$ gas production, suggests that the increase in $4 \mathrm{~h}$ gas production of any feed may be predicted from its organic nutrient profile, offering the potential to determine the optimal feeding level of sarsaponin in any TMR based on its nutrient profile.

(C) 2008 Elsevier B.V. All rights reserved.

Keywords: Fermentation; Sarsaponin; Volatile fatty acids; Ammonia

\section{Introduction}

Yucca schidigera is a desert plant native to the arid deserts of the Mexican states of Baja California, Guerrero and Huajaca. It averages $4.5 \mathrm{~m}$ in height with $1 \mathrm{~m}$ leaves and is also known as "Spanish Dagger" or "Mohave Yucca" (Cheeke, 2000). Most commercial production of $Y$. schidigera is in the arid Mojave and Sonoran deserts of the southwestern United States and northwestern Mexico. In most processes, the trunk and root of the plant are harvested, mechanically macerated, ground and dried to produce a yucca powder, or squeezed in a press to produce a yucca juice, which is then concentrated by evaporation to create a yucca extract (Cheeke, 2000; Øleszek et al., 2001). The major active components of the Y. schidigera plant used as animal feed additives are the steroidal saponins (Cheeke, 1998). According to Wang et al. (2000b), steroidal saponins form complexes with cell walls of cellulolytic and amylolytic bacteria, which disrupt membrane function and cell growth of some bacterial genera, thereby reducing their numbers in the rumen. According to Wina et al. (2005), raw yucca extract contained $44 \mathrm{~g} / \mathrm{kg}$ of DM of steroidal saponins, which are the secondary plant glycosides with attached sugars (Wang et al., 2000a). However, since yucca extracts are produced to company specification, individual products contain different concentrations of sarsaponin and, therefore, may have varying anti-microbial impacts in the rumen.

Increasing rumen digestibility of carbohydrates is important to the dairy industry because it affects the amount of feed energy that is released to meet animal metabolic needs. Supplementation of anti-microbial ionophores was effective in increasing efficiency of utilization of structural carbohydrates. However the dairy industry is increasingly looking for 'natural' products that mimic the beneficial actions of ionophores, particularly in the European Union due to the recent ban of feeding ionophores to ruminants. 
In the 1980s, there was interest in use of $Y$. schidigera as a means of defaunating the rumen, which has now become a renewed subject of research because of the positive effects of defaunation on rumen metabolism. In addition, $Y$. schidigera increased ruminal volatile fatty acid (VFA) production, while decreasing methane production (Lila et al., 2003), suggesting that it may be effective in changing microbial populations and shifting the rumen carbon balance to increase carbohydrate digestion. Indeed, Goetsch and Owens (1985) reported increased ruminal digestion of medium and low concentrate diets that were supplemented with sarsaponin at $0.13 \mathrm{~g} / 100 \mathrm{~kg} \mathrm{BW} / \mathrm{d}$, the principle saponin in $Y$. schidigera extracts (YSEs) (Kaneda et al., 1987). A current focus of $Y$. schidigera research is to better understand the ruminal carbon shift among fermentation end-products caused by feeding it, and identify diets that maximize this effect.

Our objectives were to determine the sarsaponin concentration in four commercial sources of $Y$. schidigera, and utilize one at increasing dietary levels in an in vivo study with lactating dairy cows to create rumen fluid adapted to those increasing levels of the YSE. These adapted rumen fluids were then used in an in vitro gas production study to determine how impacts of increasing feeding levels of YSE on rumen fluid impacted gas production and aNDFom digestion among feeds. The hypothesis was that supplementation of YSE could potentially alter the rumen microbial population, perhaps to impact digestion of nutrients differently, thereby increasing or decreasing gas production to differing extents in vitro, which could impact digestion of feeds differently based upon their nutrient profiles. This could allow identification and selection of diets that would optimize positive effects of YSE supplementation. Efficacy of the selected YSE product was simultaneously evaluated in an in vivo study with lactating dairy cows to determine its effects on rumen ammonia $\mathrm{N}$ levels, rumen VFA concentrations and molar proportions, rumen $\mathrm{pH}$, rumen protozoal counts as well as milk production and composition, and BW change, when fed at increasing levels to the cows.

\section{Materials and methods}

\subsection{Yucca schidigera products}

The Y. schidigera sarsaponin products Micro-Aid ${ }^{\circledR}$ (Distributors Processing Inc., Porterville, CA) De-Odorase ${ }^{\circledR}$ (Alltech Inc., Nicholasville, KY) Monterey Sarsaponin $15^{\circledR}$ (Monterey Ag Resources, Fresno, CA) and DK Sarsaponin 30 ${ }^{\circledR}$ (Desert King International, San Diego, CA) were assayed for sarsaponin content as outlined in Section 2.5.1.

\subsection{Cows}

Four ruminally cannulated (Bar Diamond, Parma, ID, USA; plastisol) late lactation $(298 \pm 32.4$ DIM) Holstein cows $(810 \pm 54.7 \mathrm{~kg} \mathrm{BW})$ were used in a $4 \times 4$ Latin Square design experiment with 14-d periods and housed in a sand bedded free stall pen equipped with Calan gates (American Calan Inc., Northwood, NH, USA). There was a 7-d adaptation period to the basal ration prior to the start of period 1. The study took place in June/August of 2006 when daytime high temperatures averaged $35-40^{\circ} \mathrm{C}$. Cows were fed a total mixed 
ration (TMR) twice daily in equal amounts at 06:30 and 18:30 h just after milking at 06:00 and 18:00 h.

\subsection{Rations fed}

The TMR was the same throughout the study and consisted of $361 \mathrm{~g} / \mathrm{kg}$ alfalfa hay, $166 \mathrm{~g} / \mathrm{kg}$ steam-flaked corn grain, $111 \mathrm{~g} / \mathrm{kg}$ steam-rolled barley grain, $34 \mathrm{~g} / \mathrm{kg}$ dried distillers grains, $95.6 \mathrm{~g} / \mathrm{kg}$ whole cottonseed, $55 \mathrm{~g} / \mathrm{kg}$ beet pulp, $20.7 \mathrm{~g} / \mathrm{kg}$ soybean meal, $120 \mathrm{~g} / \mathrm{kg}$ almond hulls, $8 \mathrm{~g} / \mathrm{kg}$ of a rumen inert fat, $3.5 \mathrm{~g} / \mathrm{kg}$ salt and $17.3 \mathrm{~g} / \mathrm{kg}$ mineral mixture. The YSE was added to the basal TMR to provide 0,50,100 or $150 \mathrm{~g}$ of Monterey Sarsaponin $15^{\circledR} /$ cow/d, or approximately $0,5,10$, or $15 \mathrm{~g}$ of sarsaponin/cow/d.

\subsection{Measurements}

\subsubsection{Milk production and composition}

Cows were milked twice daily at 06:00 and 18:00 h in a single six herringbone style milking parlor. Milk weights were measured daily by Westfalia milk meters and samplers (Westfalia, Naperville, IL, USA). Milk samples were preserved with a bronopol/natamycin preservative and transported to the UC Davis Nutrition Lab to be analyzed by infrared spectroscopy (Foss, Eden Prairie, MN, USA) for fat, crude protein (CP) and lactose.

\subsubsection{Rumen fluid}

Rumen fluid was collected by inserting an $80-\mathrm{cm}$ fixed tube with numerous 5-mm holes at 2-h post-feeding on the 9th and 14th d of each experimental period and the $\mathrm{pH}$ was immediately determined using a Cole Parmer $\mathrm{pH}$ meter (Cole Parmer Instrument Company, Chicago, IL, USA). Rumen fluid was immediately transported to the laboratory in a prewarmed thermos bottle, strained through two sheets of cheesecloth, and centrifuged at $500 \times g$ for $10 \mathrm{~min}$ at $26^{\circ} \mathrm{C}$, and supernatant was stored at $-11^{\circ} \mathrm{C}$ for later determination of VFA and ammonia N. A separate sample $(8 \mathrm{~mL})$ of strained rumen fluid was collected and added to $2 \mathrm{~mL}$ of $250 \mathrm{~g} / \mathrm{kg} \mathrm{NaCl}$ formaldehyde (Fenn and Leng, 1990) and stored at $4{ }^{\circ} \mathrm{C}$ for later determination of protozoal counts by a Bright-line Neubaur hemacytometer (Hausser Scientific, Horsham, PA, USA).

On the 12th and 13th d of each period, rumen fluid was separately collected, as described above, at $2 \mathrm{~h}$ post-feeding from two of the four cows such that each of the four cows was collected once in the $2 \mathrm{~d}$. Each sample was filtered through two sheets of cheesecloth and utilized, by cow, for $27 \mathrm{~h}$ in an in vitro gas production procedure (as described by Menke and Steingass, 1988) using 11 feedstuffs that included samples of a low and high aNDFom alfalfa hay, corn silage, beet pulp, corn grain, dried corn distillers grains, soybean meal, almond hulls, barley grain, whole crop wheat silage and whole linted cottonseed. Each feed utilized in the in vitro gas production technique was ground to pass a 1-mm screen on a model 4 Wiley Mill. An aNDFom analysis was also completed on each feedstuff after the in vitro gas production procedure to determine total digestible aNDFom of each feedstuff and the impact of rumen fluid from cows fed increasing levels of the YSE on it. 


\subsection{Analytical procedures and calculations}

\subsubsection{Basal TMR, Orts, YSE analysis}

Feeds were ground to pass a 1-mm screen on a model 4 Wiley Mill, and DM was determined by gravimetric loss of free water from heating to $105^{\circ} \mathrm{C}$ for $2 \mathrm{~h}$ (Reuter et al., 1986). Acid detergent fibre (ADFom) and lignin(sa) were determined using Ankom Technology (AOAC, 1997, Method \#973.18). Neutral detergent fibre analyses included a heat-stable amylase (Van Soest et al., 1991) and are expressed both inclusive (aNDF) and exclusive (aNDFom) of residual ash. Ash was determined by gravimetric determination by incineration at $550{ }^{\circ} \mathrm{C}$ for $3 \mathrm{~h}$. Total $\mathrm{N}$ was determined with a $\mathrm{N}$ gas analyzer utilizing an induction furnace and thermal conductivity (LECO FP-528, AOAC, 1997, Method \#990.03). $\mathrm{P}, \mathrm{Na}, \mathrm{Cl}, \mathrm{Zn}, \mathrm{Mn}, \mathrm{Fe}, \mathrm{Co}, \mathrm{S}, \mathrm{Ca}$, and $\mathrm{Mg}$ levels were determined by microwave acid digestion and dissolution of the sample and quantitative determination by AAS or ICP-AES (Sah and Miller, 1992; Meyer and Keliher, 1992). Total K was determined using a $2 \mathrm{~g} / \mathrm{kg}$ acetic acid extraction, then quantitatively by AES (Johnson and Ulrich, 1959). Total N insoluble in $\mathrm{AD}$ was determined in $\mathrm{AD}$ residue by $\mathrm{N}$ Gas Analyzer using an induction furnace and thermal conductivity (LECO FP-528, AOAC, 1997, Method \#990.03). Total Se content was determined by nitric/perchloric acid digestion and dissolution and vapor generation by ICP-AES (Tracy and Moeller, 1990). Glucose, fructose, and sucrose were determined by HPLC (Johansen et al., 1996), and starch was determined by enzymatic hydrolysis, then HPLC of the resultant glucose (Smith, 1969). Sarsaponin content of all four YSE products (Table 1) was determined by multiple methanol extractions, evaporated and partitioned between $n$-butanol and water (Salem et al., 2006).

\subsubsection{Calculations}

The potential extent and rate of gas production were determined using the one-pool exponential model of Blümmel et al. (1997) as

$$
\text { Gas }=E\left(1-\mathrm{e}^{-k t}\right)
$$

where $E$ is the potential cumulative gas production, $k$ the rate of gas production and $t$ is the time.

The gross energy concentration in milk was calculated based on measured production characteristics according to Tyrell and Reid (1965) as

$$
\begin{aligned}
& \text { milk energy }(\mathrm{MJ} / \mathrm{kg}) \\
& =4.184 \times\left(\frac{((41.63 \text { Fat })+(24.13 \text { Protein })+(21.60 \text { Lactose }))-11.72}{1000}\right) \times 2.204
\end{aligned}
$$

where fat $=$ milk fat $\mathrm{g} / \mathrm{kg}$ milk, protein $=$ milk protein $\mathrm{g} / \mathrm{kg}$ milk, lactose $=$ milk lactose $\mathrm{g} / \mathrm{kg}$ milk. The milk energy output was then calculated as

milk energy output $(\mathrm{MJ} / \mathrm{d})=$ NE milk $(\mathrm{MJ} / \mathrm{kg}) \times$ milk yield $(\mathrm{kg} / \mathrm{d})$

The energy in body weight $(\mathrm{BW})$ change was determined as

BW energy $(\mathrm{MJ} / \mathrm{d})=4.184 \times(\mathrm{BW}$ change $(\mathrm{kg} / \mathrm{d}) \times 4.92$ or 5.12$)$ 
where BW change $=$ daily $\mathrm{BW}$ change of the cow, and 4.92 or 5.12 were assigned to loss (4.92) versus gain (5.12) by cow within period (NRC, 1989).

The energy of maintenance was calculated as

$$
\text { maintenance energy }(\mathrm{MJ} / \mathrm{d})=4.184 \times\left(\mathrm{BW}(\mathrm{kg} / \mathrm{d})^{0.75} \times 0.08\right)
$$

where $\mathrm{BW}$ is in $\mathrm{kg} / \mathrm{d}(\mathrm{NRC}, 1989)$.

The NE of lactation was calculated as

$$
\begin{aligned}
\text { NE output }(\mathrm{MJ} / \mathrm{d})= & \text { milk energy }(\mathrm{MJ} / \mathrm{d})+\mathrm{BW} \text { change energy }(\mathrm{MJ} / \mathrm{d}) \\
& + \text { maintenance energy }(\mathrm{MJ} / \mathrm{d})
\end{aligned}
$$

Finally, the NE density of the TMR was calculated as

$$
\mathrm{NE}(\mathrm{MJ} / \mathrm{kg} \mathrm{DM})=\frac{\mathrm{NE} \text { output }(\mathrm{MJ} / \mathrm{d})}{\text { DM intake }(\mathrm{kg} / \mathrm{d})}
$$

\subsection{Statistical analysis}

Differences in in vitro measurements (i.e., Table 3) were determined using the PROC GLM procedure of SAS (2002) with cow, period, YSE treatment level, test feed and the treatment $(\mathrm{T})$ by feed $(\mathrm{F})$ interaction as dependent variables in a factorial design within a $4 \times 4$ Latin Square experiment. In the absence of an $\mathrm{F} \times \mathrm{T}$ interaction, YSE effects were determined as linear and quadratic contrasts within SAS as defined by Steel and Torrie (1980). In the case of an $\mathrm{F} \times \mathrm{T}$ interaction, differences in in vitro measurements, within feed, were determined using the PROC GLM procedure of SAS (2002) with cow, period and YSE treatment level as dependent variables in a factorial design within a $4 \times 4$ Latin Square experiment. YSE effects were determined as linear and quadratic contrasts within SAS as defined by Steel and Torrie (1980). Significance was accepted if $\mathrm{P}<0.05$.

Differences in in vitro measurements (i.e., Tables 4 and 5) were determined using the PROC GLM procedure of SAS (2002) with cow, period and YSE treatment level as dependent variables in a factorial design within a $4 \times 4$ Latin Square experiment. The YSE effects were determined as linear and quadratic contrasts within SAS as defined by Steel and Torrie (1980). Significance was accepted if $\mathrm{P}<0.05$.

Multiple regression analysis was used to predict increases in gas production (i.e., Table 7) based on feedstuff chemical composition (i.e., ash, fat, $\mathrm{CP}$, aNDFom, in vitro aNDF digestible at $30 \mathrm{~h}$ (i.e., dNDF30), iNDF, starch) and dose level of the YSE using the PROC STEPWISE (BACKWARD) procedure of SAS.

\section{Results}

\subsection{Y. schidigera products}

As this study was designed to evaluate the bioactivity of sarsaponin, it was important to select a product that was a pure yucca extract and not one that was blended with other 
Table 1

Sarsaponin composition (DM basis, $\mathrm{g} / \mathrm{kg}$ ) of four Yucca schidigera extracts

\begin{tabular}{lr}
\hline Monterey Sarsaponin $15^{\circledR}$ & 95.4 \\
Alltech De-Odorase ${ }^{\circledR}$ & 170.6 \\
Desert King, DK Sarsaponin $30^{\circledR}$ & 189.1 \\
DPI Micro-Aid ${ }^{\circledR}$ & 181.6 \\
SEM & 0.097 \\
\hline
\end{tabular}

potentially bioactive constituents. Of the four major commercially available $Y$. schidigera products, two claim their products to be " $100 \%$ Natural Pure $Y$. schidigera powder," being DK Sarsaponin $30^{\circledR}$ and Monterey Sarsaponin $15^{\circledR}$. As the Monterey Sarsaponin $15^{\circledR}$ product was much less concentrated than the other three products (Table 1), and could be added to TMR of the cows at higher levels thereby increasing allocation and mixing accuracy, it was used for the in vivo study. A more detailed analysis for secondary compounds was completed on the Monterey Sarsaponin $15^{\circledR}$ product supplement (Table 2).

The TMR (Table 2) had a chemical composition that met or exceeded recommended nutrient requirements NRC (1989) of late lactation dairy cows.

\subsection{In vitro study}

There was no effect of treatment on digestibility of aNDFom at $27 \mathrm{~h}$ of in vitro fermentation. However, there was a strong linear effect $(\mathrm{P}=0.002)$ for increased extent of gas production (Table 3$)$, at an increasing rate $(\mathrm{P}=0.08)$. There was a quadratic effect $(\mathrm{P}=0.01)$ on rate of gas production, with the $50 \mathrm{~g}$ feeding level of YSE being near the maximum.

At $4 \mathrm{~h}$ of fermentation (Table 3$)$, gas production increased linearly $(\mathrm{P}<0.001)$ at a decreasing rate $(\mathrm{P}=0.002)$. However this differed among feeds $(\mathrm{F} \times \mathrm{T}: \mathrm{P}<0.001)$ with gas production increasing linearly for almond hulls $(\mathrm{P}=0.04)$, corn silage $(\mathrm{P}=0.06)$, soybean meal $(\mathrm{P}=0.02)$ and wheat silage $(\mathrm{P}=0.09)$, while increasing linearly $(\mathrm{P}=0.04)$, at a decreasing rate (quadratic $\mathrm{P}=0.01$ ) for barley grain where maximum gas production occurred at about the $50 \mathrm{~g}$ YSE feeding level, similar to beet pulp $(\mathrm{P}=0.08)$.

At $24 \mathrm{~h}$ of incubation, no feed showed convincing impacts of YSE addition, in spite of a feed by treatment interaction $(\mathrm{P}<0.001)$, although overall gas production increased linearly $(\mathrm{P}=0.03)$.

\subsection{In vivo study}

Rumen $\mathrm{pH}$ was not influenced by YSE supplementation (Table 4), but molar proportions of propionate had a linear tendency $(\mathrm{P}=0.08)$ and quadratic effect $(\mathrm{P}=0.04)$ to maximum production at intermediate YSE levels. The acetate:propionate ratio also had a tendency to minimum values at intermediate YSE feeding levels (quadratic $\mathrm{P}=0.06$ ). Rumen fluid ammonia $\mathrm{N}$ concentrations had a tendency $(\mathrm{P}=0.06)$ to decrease linearly, but protozoal counts were not influenced by YSE supplementation.

Neither DM intake nor milk production, or its components (Table 5), were influenced by YSE supplementation. Only BW change and maintenance energy had a linear tendency $(\mathrm{P}=0.07)$ to increase with increasing levels of YSE supplementation. 
Table 2

Chemical composition ( $\mathrm{g} / \mathrm{kg} 105^{\circ} \mathrm{C} \mathrm{DM}$ basis) except trace minerals as noted of the basal TMR and Monterey Sarsaponin $15^{\circledR}$

\begin{tabular}{|c|c|c|c|c|}
\hline & Total mixed ration & S.E. & Monterey Sarsaponin $15^{\circledR a}$ & S.E. \\
\hline Dry matter (g/kg) & 921 & 2.4 & 958 & 1.5 \\
\hline Organic matter & 930 & 2.4 & 888 & 1.2 \\
\hline aNDF & 289 & 5.7 & 272 & 0.8 \\
\hline aNDFom & 280 & 5.8 & 290 & 0.9 \\
\hline ADFom & 205 & 4.2 & $\mathrm{NA}^{\mathrm{b}}$ & \\
\hline Lignin(sa) & 53 & 0.9 & NA & \\
\hline Starch & 139 & 9.1 & 5 & $<0.1$ \\
\hline Glucose (free) & 16.4 & 1.38 & 5 & $<0.1$ \\
\hline $\mathrm{CP}$ & 183.1 & 0.57 & NA & \\
\hline AD-insoluble CP & 13.1 & 0.07 & NA & \\
\hline $\mathrm{Ca}$ & 8.5 & 0.27 & 22.6 & 0.09 \\
\hline $\mathrm{P}$ & 4.2 & 0.10 & 0.8 & $<0.10$ \\
\hline $\mathrm{K}$ & 14.7 & 1.00 & 7.5 & $<0.10$ \\
\hline $\mathrm{Mg}$ & 5.0 & 0.14 & 2.0 & $<0.10$ \\
\hline $\mathrm{S}$ & 2.8 & 0.06 & 0.7 & $<0.10$ \\
\hline $\mathrm{Na}$ & 4.3 & 0.12 & 0.5 & $<0.10$ \\
\hline $\mathrm{Cl}$ & 5.2 & 0.36 & NA & \\
\hline \multicolumn{5}{|l|}{$(\mathrm{mg} / \mathrm{kg})$} \\
\hline $\mathrm{Zn}$ & 82 & 2.7 & 25 & 0.5 \\
\hline $\mathrm{Mn}$ & 66 & 1.9 & 22 & 0.3 \\
\hline $\mathrm{Fe}$ & 311 & 12.8 & 1150 & 9.1 \\
\hline $\mathrm{Cu}$ & 16.0 & 1.43 & 16.7 & 0.17 \\
\hline $\mathrm{Se}$ & 0.56 & 0.041 & 0.05 & $<0.01$ \\
\hline \multicolumn{5}{|c|}{ Secondary compound fractions $(\mathrm{g} / \mathrm{kg})$} \\
\hline Total phenolics & & & 20.5 & \\
\hline Saponins & & & 95.4 & \\
\hline Alkaloids & & & $<0.0$ & \\
\hline Aqueous fraction & & & 20.4 & \\
\hline
\end{tabular}

a The Monterey Sarsaponin $15^{\circledR}$ was added at increasing levels to the basal diet as described in the text.

b NA, not assayed.

\section{Discussion}

Increasing forestomach digestibility of carbohydrates in dairy rations as a way to increase NE level has been a long-term goal of dairy cattle farmers. However, due to concerns of consumers about feed supplements and treatments, particularly with respect to residues of antibiotics that dairy cattle have been fed impacting human antibiotic resistance (e.g., the recent European Union feed ban of antibiotic growth promoters), dairy researchers have increased research efforts on ionophore mimicking compounds that have 'natural' origins, such as secondary compounds in plants. Interest in the use of sarsaponin, due to its potentially beneficial effects on rumen metabolism, has made supplementation of sarsaponin containing plants such as $Y$. schidigera, of renewed interest.

This study focused on establishing in vitro responsiveness of gas production of several common dairy feedstuffs to rumen fluid from cows fed a $Y$. schidigera extract at increasing 
Table 3

Fibre digestion and gas production as impacted by YSE feeding level to the cows that produced rumen fluid inoculum

\begin{tabular}{|c|c|c|c|c|c|c|c|c|}
\hline & \multicolumn{4}{|c|}{ Treatment (g YSE/cow/d) } & \multirow[t]{2}{*}{ S.E.M. } & \multicolumn{3}{|l|}{$\mathrm{P}$} \\
\hline & 0 & 50 & 100 & 150 & & $\mathrm{~L}$ & Q & $\mathrm{F} \times \mathrm{T}^{\mathrm{a}}$ \\
\hline \multicolumn{9}{|l|}{ Fibre digestion } \\
\hline $\mathrm{dNDF}_{27}(\mathrm{mg}$ NDF digested at $27 \mathrm{~h} / \mathrm{g} \mathrm{NDF})$ & 353 & 358 & 353 & 391 & 1.4 & 0.17 & 0.34 & 0.99 \\
\hline \multicolumn{9}{|l|}{ Gas parameters } \\
\hline Extent (mL gas/g of substrate) & 222.5 & 221.0 & 226.5 & 237.0 & 0.7 & 0.002 & 0.08 & 0.99 \\
\hline Rate (mL gas/(h g of substrate)) & 0.595 & 0.645 & 0.615 & 0.605 & 0.0022 & 0.96 & 0.01 & 0.78 \\
\hline At $4 \mathrm{~h}$ of incubation & 78.5 & 87.5 & 89.0 & 89.0 & 0.27 & $<0.0001$ & 0.002 & $<0.0001$ \\
\hline Alfalfa (low NDF) & 95.9 & 103.4 & 106.2 & 109.2 & 1.13 & 0.14 & 0.70 & \\
\hline Alfalfa (high NDF) & 72.4 & 82.8 & 80.2 & 81.3 & 0.75 & 0.20 & 0.26 & \\
\hline Almond hulls & 87.2 & 89.5 & 96.9 & 95.4 & 0.56 & 0.04 & 0.51 & \\
\hline Barley grain & 107.4 & 122.8 & 120.3 & 117.0 & 0.45 & 0.04 & 0.01 & \\
\hline Beet pulp & 105.5 & 124.0 & 120.8 & 113.5 & 1.2 & 0.47 & 0.08 & \\
\hline Corn grain & 80.3 & 99.7 & 97.4 & 91.7 & 2.08 & 0.52 & 0.27 & \\
\hline Corn silage & 68.5 & 77.4 & 84.9 & 80.4 & 0.83 & 0.06 & 0.16 & \\
\hline Dried distillers grains & 37.0 & 41.2 & 42.2 & 43.3 & 0.57 & 0.17 & 0.62 & \\
\hline Wheat silage & 77.9 & 81.8 & 84.9 & 88.3 & 0.76 & 0.09 & 0.95 & \\
\hline Whole cottonseed & 60.0 & 63.8 & 67.2 & 68.9 & 0.74 & 0.12 & 0.80 & \\
\hline At $24 \mathrm{~h}$ of incubation & 209.0 & 210.5 & 211.0 & 217.0 & 1.10 & 0.03 & 0.32 & $<0.0001$ \\
\hline Alfalfa (low NDF) & 185.7 & 194.7 & 195.3 & 185.4 & 1.51 & 0.99 & 0.26 & \\
\hline Alfalfa (high NDF) & 174.0 & 181.2 & 176.5 & 182.9 & 1.20 & 0.44 & 0.95 & \\
\hline Almond hulls & 196.5 & 202.5 & 204.8 & 201.5 & 0.99 & 0.47 & 0.39 & \\
\hline Barley grain & 272.9 & 272.9 & 267.5 & 278.8 & 1.50 & 0.73 & 0.48 & \\
\hline Beet pulp & 322.4 & 320.3 & 310.5 & 342.0 & 2.43 & 0.40 & 0.22 & \\
\hline Corn grain & 288.7 & 285.7 & 294.8 & 304.9 & 1.37 & 0.11 & 0.38 & \\
\hline Corn silage & 197.5 & 200.9 & 198.7 & 211.0 & 1.11 & 0.17 & 0.45 & \\
\hline Dried distillers grains & 93.4 & 100.7 & 95.3 & 102.3 & 0.61 & 0.17 & 0.97 & \\
\hline Soybean meal & 204.4 & 183.4 & 184.0 & 201.8 & 1.87 & 0.87 & 0.08 & \\
\hline Wheat silage & 191.2 & 194.8 & 193.4 & 195.7 & 0.91 & 0.57 & 0.88 & \\
\hline Whole cottonseed & 174.7 & 177.5 & 198.8 & 182.7 & 2.62 & 0.47 & 0.50 & \\
\hline
\end{tabular}

${ }^{a}$ Feed $(\mathrm{F}) \times$ YSE treatment $(\mathrm{T})$ interaction. 
Table 4

Rumen parameters as influenced by YSE feeding level

\begin{tabular}{|c|c|c|c|c|c|c|c|}
\hline & \multicolumn{4}{|c|}{ Treatment (g YSE/cow/d) } & \multirow[t]{2}{*}{ S.E.M. } & \multicolumn{2}{|l|}{$\mathrm{P}$} \\
\hline & 0 & 50 & 100 & 150 & & $\mathrm{~L}$ & Q \\
\hline Rumen pH & 6.11 & 6.08 & 6.10 & 6.16 & 0.033 & 0.44 & 0.41 \\
\hline Ammonia N (mg/L) & 126.1 & 113.1 & 97.6 & 88.2 & 0.83 & 0.06 & 0.90 \\
\hline Total VFA (mM/L) & 119.3 & 114.2 & 99.7 & 106.4 & 6.83 & 0.28 & 0.58 \\
\hline \multicolumn{8}{|l|}{ VFA (mM/L) } \\
\hline Acetate & 63.5 & 62.7 & 62.0 & 63.1 & 0.45 & 0.56 & 0.22 \\
\hline Butyrate & 13.4 & 13.4 & 13.7 & 13.1 & 0.28 & 0.83 & 0.49 \\
\hline Propionate & 20.3 & 21.0 & 21.3 & 20.9 & 0.14 & 0.08 & 0.04 \\
\hline Valerate & 16.8 & 17.1 & 17.9 & 17.9 & 0.63 & 0.40 & 0.80 \\
\hline Isovalerate & 10.6 & 10.9 & 10.0 & 10.1 & 0.55 & 0.56 & 0.89 \\
\hline A:P ratio & 3.12 & 2.98 & 2.91 & 3.02 & 0.037 & 0.17 & 0.06 \\
\hline Protozoa (million cells $/ \mathrm{cm}^{3}$ ) & 0.54 & 0.53 & 0.45 & 0.47 & 0.030 & 0.19 & 0.72 \\
\hline
\end{tabular}

Table 5

Animal production parameters as influenced by YSE feeding level

\begin{tabular}{|c|c|c|c|c|c|c|c|}
\hline & \multicolumn{4}{|c|}{ Treatment (g YSE/cow/d) } & \multirow[t]{2}{*}{ S.E.M. } & \multicolumn{2}{|l|}{$\mathrm{P}$} \\
\hline & 0 & 50 & 100 & 150 & & $\mathrm{~L}$ & Q \\
\hline \multicolumn{8}{|l|}{ Intake } \\
\hline $\mathrm{DM}(\mathrm{kg} / \mathrm{d})$ & 24.34 & 24.88 & 24.49 & 24.09 & 0.620 & 0.70 & 0.48 \\
\hline aNDFOM (kg/d) & 6.82 & 6.97 & 6.86 & 6.75 & 0.116 & 0.69 & 0.48 \\
\hline aNDFOM (g/kg BW) & 36.0 & 35.3 & 36.3 & 36.5 & 0.750 & 0.62 & 0.72 \\
\hline Crude protein $(\mathrm{kg} / \mathrm{d})$ & 4.46 & 4.56 & 4.48 & 4.41 & 0.076 & 0.69 & 0.48 \\
\hline $\mathrm{N}$ efficiency ( $\mathrm{g}$ milk $\mathrm{N} / \mathrm{N}$ intake) & 0.238 & 0.230 & 0.217 & 0.235 & 0.0129 & 0.70 & 0.34 \\
\hline $\mathrm{NE}(\mathrm{MJ} / \mathrm{kg})^{\mathrm{a}}$ & 6.02 & 6.49 & 7.53 & 7.15 & 0.161 & 0.37 & 0.68 \\
\hline \multicolumn{8}{|l|}{ Yield (kg/d) } \\
\hline Milk & 33.48 & 33.54 & 33.85 & 33.35 & 1.048 & 0.99 & 0.80 \\
\hline Fat & 1.18 & 1.24 & 1.28 & 1.17 & 0.096 & 0.98 & 0.42 \\
\hline Crude protein & 1.09 & 1.08 & 1.07 & 1.06 & 0.037 & 0.62 & 0.96 \\
\hline Lactose & 1.50 & 1.60 & 1.60 & 1.55 & 0.084 & 0.73 & 0.46 \\
\hline \multicolumn{8}{|l|}{ Components (g/kg) } \\
\hline Fat & 34.9 & 36.7 & 37.1 & 35.1 & 0.15 & 0.86 & 0.26 \\
\hline Crude protein & 32.3 & 31.9 & 31.4 & 31.6 & 0.03 & 0.13 & 0.46 \\
\hline Lactose & 44.5 & 46.5 & 46.3 & 45.4 & 0.12 & 0.67 & 0.28 \\
\hline Milk energy (MJ/kg) & 2.89 & 3.01 & 3.01 & 2.89 & 0.013 & 0.93 & 0.25 \\
\hline \multicolumn{8}{|l|}{ Body weight } \\
\hline Mean (kg) & 814 & 821 & 818 & 831 & 4.9 & 0.07 & 0.56 \\
\hline Change (kg/d) & -0.07 & 0.61 & 1.27 & 0.91 & 1.169 & 0.51 & 0.67 \\
\hline \multicolumn{8}{|l|}{ Net energy balance $(\mathrm{MJ} / \mathrm{d})$} \\
\hline Milk & 97.7 & 101.3 & 103.0 & 97.5 & 4.01 & 0.97 & 0.48 \\
\hline BW change & -0.6 & 13.5 & 27.9 & 20.4 & 16.40 & 0.51 & 0.68 \\
\hline Maintenance & 51.0 & 51.3 & 51.2 & 51.8 & 0.02 & 0.07 & 0.59 \\
\hline Total NE output & 148.2 & 182.1 & 182.1 & 169.7 & 17.47 & 0.52 & 0.58 \\
\hline
\end{tabular}

${ }^{a}$ Calculated from measured animal NE outputs and measured animal DM intake. 


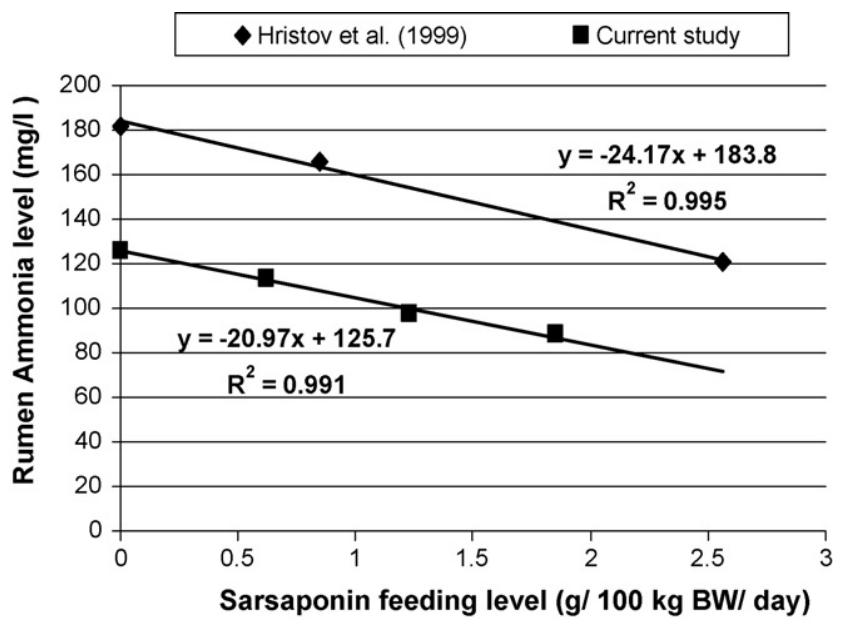

Fig. 1. Comparison of rumen ammonia level vs. dose of sarsaponin.

levels, and whether this responsiveness could be predicted from their chemical composition in order to predict the response to sarsaponin addition in dairy rations based upon the chemical composition of feedstuffs.

\subsection{Impacts of YSE on rumen fermentation}

Changes in ruminal ammonia $\mathrm{N}$ concentrations varied amongst studies that fed YSE, although the majority report a reduction. For example, YSE supplementation decreased ruminal ammonia $\mathrm{N}$ concentration in the in vivo studies of Hristov et al. (1999), Gibson et al. (1985), Goetsch and Owens (1985), Hussain and Cheeke (1995) and Pen et al. (2006). In the current study, rumen ammonia $\mathrm{N}$ levels tended $(\mathrm{P}=0.06)$ to decrease with increased YSE level in a similar way to Hristov et al. (1999), one of only two studies known to have fed sarsaponin from YSE at the high levels utilized in the current study (Fig. 1).

According to Wallace et al. (1994), the glyco-component of the sarsaponin molecule in YSE binds with ammonia. However this binding may be limited, and Wallace et al. (1994) suggested that most of the depression in rumen ammonia was actually due to decreased proteolysis in the rumen caused by anti-protozoal activity of sarsaponin in the rumen, rather than the affinity of glyco-components for ammonia. In the current study, very high levels of YSE were fed and, since it was suggested by Wang et al. (1997) that protease activity may be higher at high saponin feeding levels (i.e., $>5 \mathrm{mg} / \mathrm{mL}$ ), while deaminase activity is stable preventing complete degradation of dietary protein to ammonia. Although deaminase activity was not measured in our study, a similar study (Hristov et al., 1999) utilizing doses of YSE in our range showed no change in deaminase activity at $4 \mathrm{~h}$ post-feeding, which suggests a similar response to our study, particularly since Hristov et al. (1999) measured rumen ammonia at similar times of $2-3 \mathrm{~h}$ post-feeding.

As rumen ammonia $\mathrm{N}$ levels were measured $2-3 \mathrm{~h}$ post-feeding in the current study, and because rumen ammonia $\mathrm{N}$ concentrations tend to be maximum at about $2-4 \mathrm{~h}$ post-feeding, 
it is likely that the levels measured were relatively close to the daily maximum. According to Satter and Slyter (1974), rumen bacterial growth is negatively affected by N supplies once levels reach about $50 \mathrm{mg} / \mathrm{L}$. Considering the relatively low levels of ammonia $\mathrm{N}$ in the rumen at the two highest feeding levels of YSE (i.e., 88 and $98 \mathrm{mg} / \mathrm{L}$ ), bacterial growth may have been negatively affected by low ruminal ammonia levels at other times of the day.

Bacterial species may react differently to low levels of ammonia in the rumen. According to Hungate (1966), immediately after ingestion of forage, when fibre-digesting bacteria have not yet had the opportunity to bind with newly ingested fibre particles, the feed amino acids that are soluble in rumen fluid that are not bound to carbohydrate have already been degraded. Hungate (1966) further suggested that fibre-digesting rumen bacteria utilize rumen ammonia as an $\mathrm{N}$ source thus, if the ammonia levels were to be reduced in the rumen, it would reduce ruminal fibrolytic bacterial population size and/or activity. According to Bryant (1973), amylolytic bacteria are not as dependent on ammonia as an $\mathrm{N}$ source, and may continue to grow despite a decrease in rumen ammonia levels. Thus changes in rumen bacterial populations may have occurred due to amylolytic bacteria filling niches created where fibre-digesting bacteria decreased in numbers due to reduced rumen ammonia $\mathrm{N}$ levels caused by higher YSE feeding.

\subsection{Impacts of YSE modified rumen fluid on gas production in vitro}

If amylolytic bacterial numbers and/or activity increased due to a decrease in fibredigesting bacteria, then gas produced among feedstuffs would likely change differently relative to their chemical composition. Indeed gas production from fermentation of starch containing feedstuffs seemed to increase at $4 \mathrm{~h}$ (Table 3) as YSE dose level increased, which may be consistent with the hypothesis that amylolytic bacteria in the rumen fluid increased in numbers.

Inspection of differences in gas production at $4 \mathrm{~h}$ versus $24 \mathrm{~h}$ of fermentation (Table 3 ) suggests that the linear effect $(\mathrm{P}<0.0001)$ at $4 \mathrm{~h}$ is mostly due to gas production increases between the 0 and the $50 \mathrm{~g}$ feeding level of YSE, whereas the linear effect $(\mathrm{P}=0.03)$ at $24 \mathrm{~h}$ appears to be largely driven by higher levels of YSE feeding and may have been due to rumen microbial adaptation to these YSE feeding levels (Newbold et al., 1997). According to Segal et al. (1974) glycosylation of a saponin must occur in order for saponins to become biologically active. In a study by Wang et al. (1999), where an in vitro mixed rumen microbial population was exposed to steroidal saponins, although overall saponin content was not affected, the soluble steroidal saponin content decreased suggesting that deglycosylation had occurred and rendered the steroidal saponin inactive. Results from Wang et al. (1999) also confirm the possibility that microbial adaptation can occur and may therefore necessitate higher levels of YSE feeding in order to induce an effect on gas production at longer incubation times. Deglycosylation of saponins from YSE at $4 \mathrm{~h}$ of in vitro incubation was reported (Wang et al., 2005) and is probably a major reason for differences in gas production at $4 \mathrm{~h}$ of in vitro incubation. In in vitro studies, including the current one, gas syringes are supplied with organic ammonia to prevent lack of $\mathrm{N}$ from impacting gas production due to reduced bacterial growth. Effects of ammonia on deglycosylation of saponins are not known, although it is possible that ammonia may increase the rate of saponin deglycosylation. 
Table 6

Nutrient composition (g/kg DM) of the feedstuffs evaluated

\begin{tabular}{|c|c|c|c|c|c|c|}
\hline Feed & Ash & Fat & $\mathrm{CP}$ & dNDF30 & $\mathrm{iNDF}^{\mathrm{a}}$ & Starch \\
\hline Alfalfa hay (low NDF) & 110 & 25 & 250 & 160 & 160 & 40 \\
\hline Alfalfa hay (high NDF) & 110 & 25 & 200 & 175 & 205 & 40 \\
\hline Almond hulls & 60 & 30 & 60 & 110 & 440 & 20 \\
\hline Barley grain (ground) & 30 & 20 & 130 & 83 & 68 & 580 \\
\hline Beet pulp (dehy) & 60 & 5 & 110 & 360 & 90 & 10 \\
\hline Corn grain (ground) & 20 & 45 & 101 & 50 & 50 & 720 \\
\hline Corn silage & 50 & 20 & 89 & 303 & 248 & 320 \\
\hline Cottonseed (with lint) & 40 & 210 & 230 & 180 & 220 & 20 \\
\hline Distillers dried grains & 50 & 100 & 285 & 384 & 96 & 30 \\
\hline Soybean meal $(480 \mathrm{~g} / \mathrm{kg} \mathrm{CP})$ & 50 & 15 & 540 & 18 & 42 & 120 \\
\hline Wheat silage & 80 & 20 & 115 & 270 & 330 & 280 \\
\hline
\end{tabular}

a iNDF was calculated as: aNDFom - dNDF30.

\subsection{Impacts of YSE supplementation on animal performance and implications}

Despite changes in the ruminal bacterial populations suggested from increases in in vitro gas production in starch-rich feedstuffs, and reductions in rumen ammonia concentrations, no differences in production characteristics of the cows occurred.

In the current study, 4 and $24 \mathrm{~h}$ time values for in vitro fermentation were chosen to be key points of evaluation. This was based, in the case of $4 \mathrm{~h}$, on Hungate (1966) who suggested that it was an important point for evaluation of impacts of treatments that may modify rumen fermentation because this time provided a more reliable estimation of fermentation parameters based upon the bacterial population of the rumen inoculum than longer times when the bacterial population may have changed (Hungate, 1966). Indeed, Hungate (1966) suggested that short term in vitro methods provide very reliable estimates of rates of gas production, as well as substrate wetting on lag time before fermentation begins, and offers advantages of repeatability and practicality for evaluating microbial activity in the rumen before accumulation of fermentation products occurs. The $24 \mathrm{~h}$ fermentation time period is also important, as it is used as the time to estimate feed ME values with gas production values (Menke and Steingass, 1988).

To determine if effects of increasing feeding levels of YSE on proportional increases in 4 and $24 \mathrm{~h}$ gas production among feeds could be predicted from their nutrient profiles and the YSE dose level, multivariate analysis was used to create equations to predict impacts of nutrients in the 11 feeds (Table 6) on predicted in vitro gas production increases. These equations (Table 7) describe the degree to which each nutrient and YSE dose level is responsible for proportional increases in gas production at each of the 4 and $24 \mathrm{~h}$ time periods, and provide a way to predict proportional response of any feed based on the nutrients that comprise it, and the YSE dose level.

The equations in Table 7 were then used to estimate predicted 4 and $24 \mathrm{~h}$ proportional gas increases for the ration fed to our cows and these were in turn related to the key energetic output parameter of the cows (i.e., NE output; Fig. 2). This figure suggests a correlation between the proportional $4 \mathrm{~h}$ gas value increases and the total NE output, and no correlation between NE output and proportional increases in $24 \mathrm{~h}$ gas production. This may not support 
Table 7

Compositional characteristics utilized to predict sarsaponin impacts on 4 and $24 \mathrm{~h}$ gas production in vitro based on YSE dose level and composition of the diet

\begin{tabular}{|c|c|c|c|c|}
\hline & \multicolumn{2}{|l|}{$4 \mathrm{~h}$} & \multicolumn{2}{|l|}{$24 \mathrm{~h}$} \\
\hline & Value & $\mathrm{P}$ & Value & $\mathrm{P}$ \\
\hline Intercept & 0.9933 & $<0.001$ & 0.9876 & $<0.001$ \\
\hline Dose level & 0.0252 & $<0.001$ & - & - \\
\hline$(\text { Dose level })^{2}$ & -0.0011 & $<0.001$ & 0.0000016 & 0.006 \\
\hline Ash & - & - & 0.0036 & 0.060 \\
\hline Fat & - & - & 0.0038 & $<0.001$ \\
\hline $\mathrm{CP}$ & - & - & -0.0013 & 0.002 \\
\hline iNDF & -0.000875 & 0.151 & - & - \\
\hline dNDF30 & 0.000724 & 0.254 & - & - \\
\hline Starch & 0.000591 & 0.090 & - & - \\
\hline S.E.M. & 0.019596 & & 0.01628 & \\
\hline$r^{2}$ & 0.685 & & 0.458 & \\
\hline
\end{tabular}

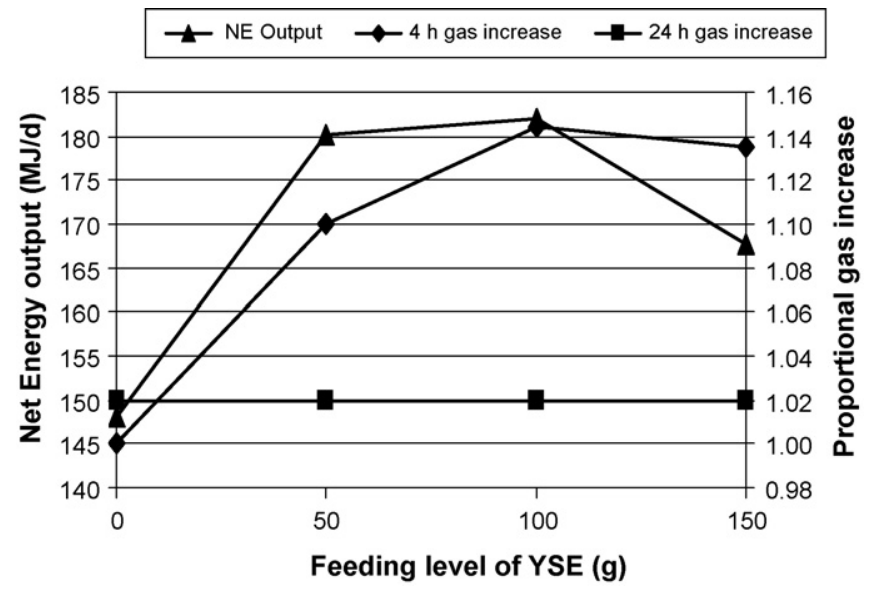

Fig. 2. Relationship between net energy output of the cows and 4 and $24 \mathrm{~h}$ predicted proportional gas increase $v s$. YSE feeding level.

Menke and Steingass (1988), who showed that $24 \mathrm{~h}$ in vitro gas production values were correlated to ME output, but it appears to support Hungate (1966) who stated that shortterm in vitro incubations are better to evaluate activity of the actual microbial population in the rumen. That the proportional $4 \mathrm{~h}$ gas production increase was correlated to the NE output of the cows in the current study suggests that it may be possible to utilize it to predict the response of mixed rations to YSE supplementation on animal NE output.

\section{Conclusions}

YSE supplementation to rations of lactating dairy cattle has been a renewed subject of research by ruminant nutritionists in the search for ionophore mimicking 'natural' products 
that can be safely fed to ruminants. Our results show that YSE is an effective way of reducing rumen ammonia levels, and YSE-modified rumen fluid affected gas production of almond hulls, barley grain, beet pulp, corn silage, soybean meal and wheat silage, sharply increasing $4 \mathrm{~h}$ gas production of starch-containing feedstuffs. This decrease in rumen ammonia $\mathrm{N}$ levels may have caused a shift in rumen bacterial populations with increased amylolytic bacterial numbers at the expense of fibrolytics. Despite YSE feeding having had no effect on milk production, milk components or energy balance, a correlation between NE output and proportional increases in $4 \mathrm{~h}$ gas production with increasing levels of YSE in the diet, suggests that this measure may be important in predicting responses to YSE supplementation. Multivariate analysis suggested that the increase in $4 \mathrm{~h}$ gas production of any feed, and perhaps rations, can be predicted from its nutrient profile, thereby offering the potential to optimize the YSE feeding level based on nutrients in the ration.

\section{Acknowledgement}

The authors thank Dr. Richard Zinn for comments during thesis revision of the senior author.

\section{References}

AOAC, 1997. Official Methods of Analysis, 16th ed. Association of Official Analytical Chemists, Arlington, VA, USA.

Blümmel, M., Makkar, H.P.S., Chisanga, G., Mtimuni, J., Becker, K., 1997. The prediction of DMI of temperate and tropical roughages from in vitro digestibility of African roughages in relation to ruminant live weight gain. Anim. Feed Sci. Technol. 69, 131-141.

Bryant, M.P., 1973. Nutritional requirements of the predominant rumen cellulolytic bacteria. Fed. Proc. 32, 1809-1813.

Cheeke, P.R., 1998. Toxins intrinsic to forages. In: Cheeke, P.R. (Ed.), Natural Toxicants in Feed, Forages, and Poisonous Plants, 2nd ed. Interstate Publishers, Danville, IL, pp. 275-324.

Cheeke, P.R., 2000. Actual and potential applications of Yucca schidigera and Quillaja Saponaria saponins in human and animal nutrition. Proc. Phytochem. Soc. Europe 45, 241-254.

Fenn, P.D., Leng, R.A., 1990. The effect of bentonite supplementation on ruminal protozoa density and wool growth in sheep either fed roughage based diets or grazing. Aust. J. Agric. Res. 41, 167-174.

Gibson, M.L., Preston, R.L., Pritchard, R.H., Goodall, S.R., 1985. Effect of Sarsaponin and monensin on ruminal ammonia levels and in vitro DM digestibilities. J. Anim. Sci. 61 (Suppl. 1), 492.

Goetsch, A.L., Owens, F.N., 1985. Effects of sarsaponin on digestion and passage rates in cattle fed medium to low concentrate. J. Dairy Sci. 68, 2377-2384.

Hristov, A.N., McAllister, A., Van Henk, F.H., Cheng, K.J., Newbold, C.J., Cheeke, P.R., 1999. Effect of Yucca schidigera on rumen fermentation and nutrient digestion in heifers. J. Anim. Sci. 77, 2554-2563.

Hungate, R.E., 1966. The Rumen and its Microbes. Academic Press, New York, USA.

Hussain, I., Cheeke, P.R., 1995. Effect of dietary Yucca schidigera extract on rumen and blood profiles of steers fed concentrate or roughage based diets. Anim. Feed Sci. Technol. 51, 231-242.

Johnson, C.M., Ulrich, A., 1959. Analytical Methods for Use in Plant Analysis. University of California Agriculture Experiment Station, Berkeley, CA, USA Bulletin 766, pp. 26-78.

Johansen, H.N., Glitso, V., Knudsen, K.E.B., 1996. Influence of extraction solvent and temperature on the quantitative determination of oligosaccharides from plant materials by high-performance liquid chromatography. J. Agric. Food Chem. 44, 1470-1474. 
Kaneda, N., Nakanishi, M., Staba, E.S., 1987. Steroidal constituents of Yucca schidigera plants and tissue cultures. Phytochemistry 26, 1425-1429.

Lila, Z.A., Mohammed, N., Kaneda, S., Kameda, T., Itabashi, H., 2003. Effect of sarsaponin on ruminal fermentation with particular reference to methane production in vitro. J. Dairy Sci. 86, 33303336.

Menke, K.H., Steingass, H., 1988. Estimation of the energetic feed value from chemical analysis and in vitro gas production using rumen fluid. Anim. Res. Dev. 28, 7-55.

Meyer, G.A., Keliher, P.N., 1992. An overview of analysis by inadvertively coupled plasma-atomic emission spectrometry. In: Montaser, A., Golightly, D.W. (Eds.), Inductively Coupled Plasmas in Analytical Atomic Spectrometry. VCH Publications Inc., New York, NY, USA, pp. 473-516.

Newbold, C.J., El Hassan, S.M., Wang, J., Ortega, M.E., Wallace, R.J., 1997. Influence of foliage from African multipurpose trees on activity of rumen protozoa and bacteria. Br. J. Nutr. 78, 237249.

National Research Council, 1989. Nutrient Requirements of Dairy Cattle. 6th rev. ed. Natl. Acad. Sci., Washington, DC, USA.

Øleszek, W.I., Sivek, M., Stochmal, A., Piacente, S., Pizza, C., Cheeke, P.R., 2001. Steroidal saponins of Yucca schidigera Roeszl. J. Agric. Food Chem. 49, 3292-3296.

Pen, B., Takaura, K., Yamaguchi, S., Asa, R., Takahashi, J., 2007. Effects of Yucca schidigera and Quillaja Saponaria with or without B-1,4-galacto-oligosaccharaides on ruminal fermentation, methane production, and $\mathrm{N}$ utilization in sheep. AFST 138, 75-88.

Reuter, D.J., Robinson, J.B., Peverill, K.I., Price, G.H., 1986. Guidelines for collecting, hauling, and analyzing plant materials. In: Reuter, D.J., Robinson, J.B. (Eds.), Plant Analysis An Interpretation Manual. Inkata Press, Melbourne, Australia, pp. 20-35.

Sah, R.N., Miller, R.O., 1992. Spontaneous reaction for acid dissolution of biological tissues in closed vessels. Anal. Chem. 64, 230-233.

Salem, A.Z.M., Salem, M.Z.M., El-Adawy, M.M., Robinson, P.H., 2006. Nutritive evaluations of some browse tree foliages during the dry season: secondary compounds, feed intake, and in vivo digestibility in sheep and goats. Anim. Feed Sci. Technol. 126, 251-267.

Segal, R., Shatkovsky, P., Milo-Goldzweig, I., 1974. The mechanism of saponin hemolysis in hydrolysis of the glycosidic bond. Biochem. Pharm. 23, 973-981.

Satter, L.D., Slyter, L.L., 1974. Effect of ammonia concentration on rumen microbial protein production in vitro. Br. J. Nutr. 32, 199-208.

Smith, D., 1969. Removing and analyzing total non-structural carbohydrates from plant tissue. Univ. Wisc. Agric. Exp. Sta. Res. Report 41, Madison, WI, USA.

Steel, R.G.D., Torrie, J.H., 1980. Principles and Procedures of Statistics. McGraw Hill Book Company, New York, NY, USA.

Tracy, M.L., Moeller, G., 1990. Continuous flow vapor generation for inductively coupled argon plasma spectrometric analysis. Part 1. Selenium. J. Assoc. Off. Anal. Chem. 73, 404-410.

Tyrell, H.F., Reid, J.T., 1965. Prediction of the energy value of cows milk. J. Dairy Sci. 48, 1215-1223.

Van Soest, P.J., Robertson, J.B., Lewis, R.A., 1991. Methods of dietary fiber, neutral detergent fiber, and non-starch polysaccharides in relation to animal nutrition. J. Dairy Sci. 74, 3583-3590.

Wallace, R.J., Arthaud, L., Newbold, C.J., 1994. Influence of Yucca schidigera extract on rumen ammonia concentration and rumen microorganisms. Appl. Environ. Microbiol. 60, 1762-1767.

Wang, Y., McAlliser, T.A., Newbold, C.J., Cheeke, P.R., Cheng, K.J., 1997. Effects of Yucca extract on fermentation and degradation of saponins in the Rusitec. Proc. Western Section. Am. Soc. Anim. Sci. 48, 149152.

Wang, Y., McAllister, T.A., Cheeke, P.R., Hiley, P., Cheng, K.J., 1999. Assessment of inhibitory effects of ruminal fluid on biological activity of saponins using hemolytic assay. Can. J. Anim. Sci. 79, 561564.

Wang, Y., McAllister, T.A., Yanke, L.J., Xu, Z.J., Cheeke, P.R., Cheng, K.J., 2000a. In vitro effects of steroidal saponins from Yucca schidigera extract on rumen microbial protein synthesis and rumen fermentation. J. Sci. Food Agric. 80, 2122-2214.

Wang, Y., McAllister, T.A., Yanke, L.J., Cheeke, P.R., 2000b. Effect of steroidal saponin from Yucca schidigera extract on ruminal microbes. J. Appl. Microbiol. 88, 887-896. 
Wang, Y., Greer, D., McAllister, T.A., 2005. Effect of a saponin-based surfactant on water absorption, processing characteristics and in vitro ruminal fermentation of barley grain. Anim. Feed Sci. Technol. 118, 255266.

Wina, E., Meutzel, S., Becker, K., 2005. The impact of saponins or saponin containing plant materials on ruminant production: a review. J. Agric. Food Chem. 53, 8093-8105. 